PROBLEMS

OF MANAGEMENT

IN THE $21^{\text {st }}$ CENTURY

Vol. 15 , No. 2,2020

\title{
MANAGEMENT IN A TIME OF RADICAL UNCERTAINTY
}

\author{
Marc Jacquinet \\ Open University of Lisbon, Portugal \\ E-mail: mjacquinet@gmail.com
}

Societies are still, now, indubitably, in the middle of a major sanitary and health crisis, all over. If April 2020 was a time of local lockdown in Asia, Europe and the Americas, it is expanding globally, and countries that are unable or unwilling to manage the spread of the disease are putting their health system as well as their social and economic activities under pressure, without ignoring the heavy toll on human populations.

The impact of the Sars-CoV-2 and the resulting disease for humans is already tremendous, above 3 percent of GDP for the first quarter of 2020 and above 15 or 20 percent for the whole current year. According to the World Trade Organization (WTO 2020) the decline of global trade is reckoned between 13 and $32 \%$ (OECD 2020).

As in any big social change, people's subjective experience of time has changed; remembrance of the recent past (late 2019 or early 2020) seems so long ago; whilst some distant memories are springing in the day-to-day mental wandering about what is happening now, and what is the meaning of all that in the present, and the consequences for the future, for society, local groups and humanity and how should people behave. The change is not just subjective. It touches objective dimensions of people's lives and worlds, close or faraway. What about the spread of Covid-19, overwhelmed health care systems, panic, stock market turbulence, foreclosures, sudden spike in unemployment, business closures, and reorganization of corporate activities and policy orientation? All could be associated to a sudden and unforeseen change.

Three considerations are worth brief discussion: (1) the dimension of risk in the current crisis; (2) the question of change and its necessity, namely in relation to management practice and sustainability, and, finally, (3) the question of method in management, at different levels.

Fist, the dimension of risk, in the current meltdown, is central for rethinking the problems, the difficulties experienced by corporations and workers and to design new solutions, especially for tackling climate change and sustainability.

That is what social scientists call uncertainty and it encompasses risks. Uncertainty is an overarching concept and reality which includes the other complementary notion of risk. In a way, what Ulrich Beck $(1992,2013)$ called the risk society is the self-reflection of society and sociology on the unveiling of human activities related to errors, mistakes, ignorance and complexity. This dimension of risk, how it is defined, managed, shared (in terms of costs and opportunities) and used (for imposing order or compensation). This dimension is pervasive and is related to several dimensions of social life, one is the knowledge or ignorance that characterizes the interaction of agents and group. It is crucial for democratic processes and the capacity to adapt to unexpected challenges.

The second consideration has to do with the question of sustainability and the difficulties of changing the path taken up until now. A central feature of the current Covid-19 crisis is the resistance of the unquantified, the invisible, the social respect, the relationships to other(s) and the stranger(s), the disease, the fear of the disease, and the loss of habits, friends and family members, the gathering and social interaction. This could be called the unquantified self, in contradistinction to what Deborah Lupton (2016) characterized as the quantified self. The latter 
is very present in the emergence of artificial intelligence, assessment of work, appraisal of behavior and the processes of surveillance and control. The former, the unquantified self, is much more related to democracy, freedom and family and private life, much more than work and corporate life.

There is here an opportunity for society and communities to rethink those tendencies and to bring back what matters to people: up until now, performance (for whom?) rather than flourishing (for all).

In a few words, the world has changed radically, not just in terms of daily behavior through the sanitary and health crisis and the economic downturn, but also in terms of how management is perceived, valorized and reinvented.

Third, there is a need to change the method in management, both for studying problems, such as risk, and for implementing change in corporations and business schools, namely in terms of developing new ways of looking, teaching and researching in the field. A good example is the evolution of the role played by masks in collective settings (Lynteris 2018).

The problems facing management - as academic discipline and as current practice in organizations - are much beyond the pale outlook preceding the pandemic crisis. It calls for deeper thinking about the issues, theoretically, empirically, methodologically and philosophically. In this final section, two considerations are worthwhile. First, the disciplinary divides, in and beyond management lead to the accrue necessity of a transdisciplinary or crossdisciplinary perspective. To move beyond academic and professional silos, it is necessary to adhere to some form of interdisciplinarity or cross-disciplinarity and deep reflexivity about management practice or professional routines. The cross-disciplinary routine can help view the research problems or the management issues (on the job challenges) in another perspective. The dogma of the 1980s and 2010s "there is no alternative" or TINA, is not sustainable and in the long run counterproductive, leaving social and health problems unattended.

In the present crisis, the strong disciplinary focus is both a strength and a weakness. There is no point here to insist on the strong contributions of specialization and a thorough study of specific phenomena. The weakness of specialization, both in science and in practical matters such as management, is the absence of conscious concentration, following routines, and the inability to look beyond the narrow problem, without much attention to the context, global and local, and to other dimensions of reality. The case of zoonoses is a good example. Accordingly, this disease can jump from one species to another, if the right conditions happen, and it can be either detected or people can look carefully at the right combinations of factors that can make it happen, as it was most probably the case in Huan in late 2019. Some of the factors are related to climate change, natural disasters, social unrest and political turmoil, coupled with other triggers such as drive for exotic food and animals, globalization and intensification of economic exchanges and travel. All those elements combined made a perfect storm.

Combining different scientific and professional approaches can help unveil what is going out and what emerging risks people can face. The emerging risks are either systemic risks with interconnected parts such as financial markets and institutions (such as banks) or new risks that cross boundaries, like the zoonoses that lead to the Covid-19 pandemic and the current crisis.

Second, the question of the method in research is central to better understand what management is and what are the challenges for managers and scholars beyond the limited realm of corporations and business schools, in order to include a more critical study of reality, in its social, natural, economic dimensions; and this means to perfect the way people look at things in front of them, and at the borders, to reach what matters today and in the future of daily lives, in all their complexity.

One of the central conclusions is the necessity of cooperation, not just in the search of cures and vaccines, but also in the overhaul of the economic, social and political system; and management is much part of it, in business schools, corporations and public administration. It means managing 
Marc JACQUINET. Management in a time of radical uncertainty

OF MANAGEMENT IN THE $21^{\text {st }}$ CENTURY Vol. 15 , No. 2, 2020

78

more humanely, working together to reach genuine goas for flourishing. This can be translated into better attention to sustainability and green activities, more focus on understanding risks and their consequences, and, finally, overhauling our methods of research and behaving regarding the economy and work.

\section{References}

Beck, U. (1992). Risk society: Towards a new modernity. Sage Publications.

Beck, U. (2013). World at risk. Wiley.

Lupton, D. (2016). The quantified self. Wiley.

Lynteris, C. (2018). Plague masks: The visual emergence of anti-epidemic personal protection equipment. Medical Anthropology, 37(2), 442-457. https://doi.org/10.1080/01459740.2017.123072

OECD (2020). OECD Economic Outlook, Interim Report, March 2020. OECD Publishing. https://doi.org/10.1787/7969896b-en

WTO (2020). Trade set to plunge as COVID-19 pandemic upends global economy. https://www.wto.org/ english/news_e/pres20_e/pr855_e.htm

Received: June 15, 2020

Accepted: November 12, 2019

Cite as: Jacquinet, M. (2020). Management in a time of radical uncertainty. Problems of Management in the $21^{\text {st }}$ Century, 15(2), 76-78. https://doi.org/10.33225/pmc/20.15.76

Marc Jacquinet

$\mathrm{PhD}$ in Economics, Open University of Lisbon, Portugal.

E-mail: mjacquinet@gmail.com

ORCID: https://orcid.org/0000-0003-1157-060X 